\title{
BIO-PRIMING OF SEEDS: APOTENTIAL TOOL IN THE INTEGRATED MANAGEMENT OF ALTERNARIA BLIGHT OF SUNFLOWER
}

\author{
Rao, M.S.L. ${ }^{*}$, Kulkarni, S. ${ }^{1}$, Lingaraju, S. ${ }^{1}$ and Nadaf, H.L. ${ }^{2}$
}

${ }^{1}$ Department of Plant Pathology, University of Agricultural Sciences,

Dharwad, Karnataka, India

2 B.S.P.N.S.P. University of Agricultural Sciences, Dharwad, Karnataka, India

Received: August 03, 2007

Accepted: May 22, 2009

SUMMARY

Of the different integrated seed treatment options tested for the management of Alternaria blight of sunflower, highest benefit was obtained in the seed treatment with Carbendazim+Iprodione (Quintal) at $0.3 \%$ in water along with hexaconazole foliar spray $(0.1 \%)$ followed by seed treatment with Pseudomonas fluorescens $(0.8 \%)$ in jelly+hexaconazole foliar spray. Efficacy of Pseudomonas fluorescens as seed dresser can be enhanced by bio-priming the sunflower seeds for the effective and eco-friendly management of Alternaria blight of sunflower.

\section{Key words: sunflower, Alternaria blight, integrated seed treatment options, bio-priming}

\section{INTRODUCTION}

Alternaria blight is an important fungal disease of sunflower in India and estimates of yield losses due to this disease range up to $80 \%$. The pathogen spreads through plant debris, seed and air and causes severe leaf spot resulting in premature defoliation and stem breakage. Alternaria leaf blight reduces the average flower size, number of seeds per plant, seed yield per plant, seed weight and percentage filling of seed. Average yield and oil losses in India ranged from 28 to $80 \%$ and 31 to 34\%, respectively (Balasubrahmanyam and Kolte, 1980). Hiremath et al. (1993) observed that the infection of Alternaria helianthi reduced seed germination by $35 \%$ compared with apparently healthy seeds. Integration of chemicals, plant extracts, biotic agents along with priming agents for managing plant diseases has been considered as a novel approach, as it requires low amounts of chemicals, reducing the cost of control and pollution hazards while causing minimum interfer-

* Corresponding author: 
ence with biological equilibrium (Papavizas, 1973). The use of fungicides, seed dressing chemicals, bioagents or botanicals with priming agents has become an inevitable method of disease control, particularly in sunflowers and in the absence of resistant cultivars. The infusion of fungicides into dormant seeds is a useful and efficient means of plant disease control. Acetone, dichloromethane (DCM) and polyethylene glycol (PEG) have been used to infuse systemic fungicides into seeds of a variety of crops. The infusion of systemic fungicides into soybean seeds with acetone has been shown to control damping off caused by Phytophthora megasperma var. sojae Hildebr. (Papavizas and Lewis, 1976). Seed treatment with biocontrol agents along with priming agents may serve as an important means of managing many soil and seed-borne diseases, the process often known as "bio-priming". The bio-priming seed treatment developed for control of Pythium seed rot of sh2 sweet corn combines microbial inoculation with preplant seed hydration. Bio-priming involves coating seed with a bacterial biocontrol agent such as Pseudomonas aureofaciens Kluyver AB254 and hydrating for $20 \mathrm{~h}$ under warm conditions $\left(23^{\circ} \mathrm{C}\right)$ in moist vermiculite or on moist germination blotters in a self-sealing plastic bag. The seeds are removed before radicle emergence (Callan et al., 1990).

Bio-priming process had potential advantages over simple seed coating with $P$. aureofaciens Kluyver AB254. Seed priming often results in more rapid and uniform seedling emergence and may be useful under adverse soil conditions. Sweet corn seedling emergence in Pythium-infested soil was increased by AB254 at a range of soil temperatures, but emergence at $10^{\circ} \mathrm{C}$ was slightly higher from bioprimed seeds than from seeds coated with the bacterium (Mathre et al., 1994). Accordingly, the following study was undertaken to see the efficacy of integrated seed treatment options for the management of Alternaria blight of sunflower.

\section{MATERIALS AND METHODS}

A field experiment was conducted during October 2004, at the Main Agricultural Research Station, College of Agriculture, Dharwad, Karnataka, India, to see the efficacy of integrated seed treatment options involving a seed dressing fungicide, bioagent and botanical in different priming agents along with foliar spray of $0.1 \%$ Hexaconazole at 40 DAS (days after sowing), for the management of Alternaria blight in sunflower. A sunflower hybrid KBSH-44 was used for the study under irrigated conditions. All other recommended practices were followed and applied in all treatments.

Seeds of the sunflower hybrid KBSH-44 were treated with carbendazim+ iprodione (Quintal) at $0.3 \%$ along with different organic solvents as priming agents such as polyethylene glycol (PEG 6000), acetone, dichloromethane (DCM) and glycerol and compared with a treatment with water. Pseudomonas fluorescens Migula was used for bio-priming of seeds with priming agents such as vermiculite, jelly, moist blotters, salicylic acid and compared with direct seed treatment. One hundred 
grams of sunflower seeds (the cultivar KBSH-44) were soaked for $24 \mathrm{~h}$ at $25 \pm 2{ }^{\circ} \mathrm{C}$ in $500 \mathrm{ml}$ solutions of acetone, glycerol, dichloromethane, polyethylene glycol (30\% v/ v) and water containing $0.3 \%$ of Quintal separately and dried under shade.

In bio-priming, hundred grams of sunflower seeds (the cultivar KBSH-44) were treated with the bacterial biocontrol agent $P$. fluorescens using priming agents such as vermiculite, jelly and moist blotters. After presoaking of seeds in sterile distilled water, seeds were coated with powder formulation of $P$. fluorescens at $0.8 \%$ concentration along with moist vermiculite in the proportion of 3:1 ( 3 parts of vermiculite to 1 part of seed) and mixed thoroughly to provide uniform coating. The seeds were dried in shade and stored at $25 \pm 2^{\circ} \mathrm{C}$ for $24 \mathrm{~h}$ in a self-sealing plastic bag before being tested under field conditions. For bio-priming in "Jelly" (a commercial preparation containing water absorbent, an organic polymer that absorbs, stores and then keeps releasing the moisture slowly), $10 \mathrm{~g}$ of jelly was poured into $500 \mathrm{ml}$ of cold sterilized water and kept in water for 5 to 6 hours till the small pieces turned into sparkling jelly cubes. After pre-soaking of seeds in sterilized water, seeds were coated with powder formulation of $P$. fluorescens at $0.8 \%$ concentration along with jelly cubes in 3:1 proportion as stated earlier. Such treated seeds along with the jelly cubes were stored in open beakers or in self-sealing plastic bags at $25 \pm 2{ }^{\circ} \mathrm{C}$ for $24 \mathrm{~h}$ before being tested in field conditions. For salicylic acid treatment, seeds were imbibed in concentration of $15 \mathrm{mM}$ salicylic acid for 15-20 minutes and washed in sterile water to remove the traces of acid, then air-dried and stored as stated earlier. Seeds were also treated with neem-leaf extract in combination with chemicals and bioagents at $10 \%$ concentration. The experiment was laid out in a randomized block design with three replications. The treatments were randomly allotted to the plots. A plot size of $3.0 \times 3.0 \mathrm{~m}$ was maintained with spacing of $60 \times$ $30 \mathrm{~cm}$. Observations on blight disease incidence at 45, 60 and 75 days after sowing were recorded by scoring five plants in each treatment on a 0 to 9 scale of Mayee and Datar (1986) and percent disease index (PDI) was calculated using a formula given by Wheeler (1969)

$$
\text { PDI }=\frac{\text { Sum of numerical disease ratings }}{\text { No. of plants/leaves observed }} \times \frac{100}{\text { Maximum disease rating value }}
$$

Head diameter, test weight (100-seed weight) and yield (quintal/ha) were also recorded. For benefit-cost ratio (BCR), total cost incurred for application of each treatment (including cost of chemicals and labor) was calculated. Additional benefit due to increased yield in each treatment over control was also worked out and benefit-cost ratio was calculated by dividing total cost with additional benefit.

\section{RESULTS AND DISCUSSION}

Results of this study (Table 1 and Figures 1 and 2) indicated that though the seed treatment with carbendazim+iprodione at $0.3 \%$ in poly ethylene glycol along 
Table 1: Field evaluation of integrated seed treatment options with priming agents for the management of Alternaria leaf blight of sunflower

\begin{tabular}{|c|c|c|c|c|c|c|c|c|}
\hline \multirow{2}{*}{ Tr. No } & \multirow{2}{*}{ Treatment } & \multicolumn{3}{|c|}{ Percent disease index at } & \multirow{2}{*}{$\begin{array}{c}\text { Head } \\
\text { diameter } \\
(\mathrm{cm})\end{array}$} & \multirow{2}{*}{$\begin{array}{c}\text { Test } \\
\text { weight } \\
\text { (G) }\end{array}$} & \multirow{2}{*}{$\begin{array}{l}\text { Yield } \\
\text { (q/ha) }\end{array}$} & \multirow{2}{*}{$\begin{array}{l}\mathrm{B}: \mathrm{C} \\
\text { ratio }\end{array}$} \\
\hline & & 45 DAS & 60 DAS & 75 DAS & & & & \\
\hline $\mathrm{T}_{1}$ & $\mathrm{QAH}^{*}$ & $42.18(40.51)^{\star}$ & $55.00(47.87)$ & $67.34(55.15)$ & 16.00 & 3.41 & 13.97 & 2.17 \\
\hline $\mathrm{T}_{2}$ & QDH & 40.7 (39.63) & $52.54(46.45)$ & $62.30(52.32)$ & 16.16 & 3.22 & 15.54 & 3.46 \\
\hline $\mathrm{T}_{3}$ & QGH & $38.23(38.13)$ & $56.39(48.73)$ & $63.39(53.04)$ & 17.16 & 3.43 & 15.08 & 2.63 \\
\hline $\mathrm{T}_{4}$ & QPH & $19.24(25.53)$ & $28.86(32.49)$ & 37.74 (37.89) & 25.00 & 5.51 & 17.12 & 7.94 \\
\hline $\mathrm{T}_{5}$ & QWH & $22.69(28.42)$ & $35.27(36.45)$ & $42.18(40.51)$ & 23.00 & 4.30 & 16.1 & 11.66 \\
\hline $\mathrm{T}_{6}$ & Q.H. & $24.91(29.88)$ & 38.97 (38.62) & $47.60(43.62)$ & 23.00 & 4.03 & 15.08 & 8.98 \\
\hline $\mathrm{T}_{7}$ & $\mathrm{PF}+\mathrm{H}$ & 40.7 (39.63) & $49.58(44.75)$ & $56.98(49.02)$ & 19.33 & 3.8 & 13.33 & 4.41 \\
\hline $\mathrm{T}_{8}$ & PFBLH & $39.22(38.76)$ & $46.48(43.05)$ & $52.54(46.45)$ & 19.43 & 3.78 & 15.08 & 3.49 \\
\hline $\mathrm{T}_{9}$ & PFVH & $36.26(37.00)$ & $43.66(41.36)$ & 48.59 (44.19) & 20 & 5.01 & 15.27 & 6.24 \\
\hline $\mathrm{T}_{10}$ & PFSAH & $46.12(42.78)$ & $52.43(46.45)$ & $62.90(52.61)$ & 16.5 & 3.51 & 13.53 & 4.92 \\
\hline $\mathrm{T}_{11}$ & PFJelly H & 29.60 (32.96) & 39.22 (38.76) & $45.63(42.43)$ & 23.5 & 5.45 & 15.92 & 10.53 \\
\hline $\mathrm{T}_{12}$ & $\mathrm{SAH}$ & $48.46(44.17)$ & $56.48(48.73)$ & $63.88(53.19)$ & 16 & 3.46 & 12.59 & 2.46 \\
\hline $\mathrm{T}_{13}$ & QSAH & $43.16(41.07)$ & $61.42(50.75)$ & $68.82(56.04)$ & 18.5 & 3.89 & 13.18 & 3.97 \\
\hline $\mathrm{T}_{14}$ & $\mathrm{NH}$ & $44.15(41.64)$ & $57.47(49.51)$ & $65.86(54.25)$ & 16.33 & 3.62 & 14.99 & 8.76 \\
\hline $\mathrm{T}_{15}$ & $\mathrm{NQH}$ & 40.70 (39.62) & $50.56(45.21)$ & $67.34(55.14)$ & 18.86 & 4.43 & 15.27 & 9.38 \\
\hline $\mathrm{T}_{16}$ & $\mathrm{NSAH}$ & $43.16(41.07)$ & $61.42(51.72)$ & $68.82(56.05)$ & 16.83 & 3.66 & 13.56 & 4.98 \\
\hline $\mathrm{T}_{17}$ & NPFH & $44.64(41.91)$ & $59.94(50.73)$ & $64.97(54.33)$ & 18.60 & 4.10 & 15.04 & 8.85 \\
\hline$T_{18}$ & $\begin{array}{l}\text { Hexacona- } \\
\text { zole alone }\end{array}$ & $44.7641 .95)$ & $62.00(52.06)$ & $64.71(53.55)$ & 22.83 & 3.45 & 13.36 & 4.52 \\
\hline \multirow[t]{3}{*}{$\mathrm{T}_{19}$} & Control & $61.17(51.58)$ & $67.83(55.79)$ & $76.22(60.80)$ & 13.33 & 3.18 & 11.66 & \\
\hline & S.Em \pm & 0.6410 & 0.6705 & 0.6187 & 0.3410 & 0.098 & 0.153 & \\
\hline & CD@ @ $\%$ & 2.45 & 2.57 & 1.682 & 1.311 & 0.376 & 0.589 & \\
\hline
\end{tabular}

* Figures in parentheses indicate arcsine-transformed values

\begin{tabular}{|c|c|c|}
\hline & QAH & : Quintal+acetone+hexaconazole spray \\
\hline $\mathrm{T}_{2}$ & QDH & : Quintal+dichloromethane+hexaconazole spray \\
\hline $\mathrm{T}_{3}$ & QGH & : Quintal+glycerol+hexaconazole spray \\
\hline $\mathrm{T}_{4}$ & QPH & : Quintal $(0.3 \%)+$ P.E.G. $(30 \%)+$ hexaconazole spray $(0.1 \%)$ \\
\hline $\mathrm{T}_{5}$ & QWH & : Quintal+water+hexaconazole spray \\
\hline $\mathrm{T}_{6}$ & Q.H. & : Quintal+hexaconazole spray \\
\hline $\mathrm{T}_{7}$ & $\mathrm{PF}+\mathrm{H}$ & : Direct seed treatment - Pseudomonas fluorescens +hexaconazole spray \\
\hline $\mathrm{T}_{8}$ & PFBLH & : Pseudomonas fluorescens + hydrating in moist blotter + hexaconazole spray \\
\hline$T_{9}$ & PFVH & : Pseudomonas fluorescens + vermiculite+hexaconazole spray \\
\hline $\mathrm{T}_{10}$ & PFSAH & : Pseudomonas fluorescens +salicylic acid+hexaconazole spray \\
\hline $\mathrm{T}_{11}$ & PFJelly H & : Pseudomonas fluorescens + jelly+hexaconazole spray \\
\hline $\mathrm{T}_{12}$ & $\mathrm{SAH}$ & : Salicylic acid+hexaconazole spray \\
\hline $\mathrm{T}_{13}$ & QSAH & : Quintal+salicylic acid+hexaconazole spray \\
\hline $\mathrm{T}_{14}$ & $\mathrm{NH}$ & : Neem leaf extract+hexaconazole spray \\
\hline $\mathrm{T}_{15}$ & $\mathrm{NQH}$ & : Neem leaf extract+Quintal+hexaconazole spray \\
\hline $\mathrm{T}_{16}$ & NSAH & : Neem leaf extract+salicylic acid+hexaconazole spray \\
\hline $\mathrm{T}_{17}$ & NPFH & : Neem leaf extract+Pseudomonas fluorescens + hexaconazole spray \\
\hline $\mathrm{T}_{18}$ & $\begin{array}{l}\text { Hexaconazole } \\
\text { alone }\end{array}$ & : Hexaconazole alone \\
\hline $\mathrm{T}_{19}$ & Control & : Untreated \\
\hline
\end{tabular}


with foliar spray of hexaconazole recorded least percent disease indexes of 19.24, 28.86 and $37.74 \%$ at 45,60 and 75 DAS, respectively, seed treatment with carbendazim+iprodione at $0.3 \%$ in water along with foliar spray of hexaconazole was found most effective in managing Alternaria blight with maximum benefit-cost ratio. Seed treatment of carbendazim + iprodione at $0.3 \%$ in water along with foliar spray of hexaconazole showed a disease index of $22.69 \%$ at 45 DAS, which was found on par with direct seed treatment with carbendazim +iprodione at $0.3 \%$ concentration along with foliar spray of hexaconazole. However, it showed significant difference in percent disease index at 60 and 75 DAS with disease incidence of 35.27 and $42.18 \%$, respectively, compared with the incidences of 38.97 and $47.60 \%$ at 60 and 75 DAS, respectively, obtained by direct seed treatment with carbendazim + iprodione. The bioagent Pseudomonas fluorescens performed better in "jelly" as priming agent along with foliar spray of hexaconazole, which recorded the percent disease indexes of 29.6, 39.22 and $45.63 \%$ at 45,60 and 75 DAS, respectively, which was found to be significantly superior over the other priming agents and also over the direct seed treatment with $P$. fluorescens. The seed treatment with P.fluorescens in vermiculite as priming agent also showed good response, next to "jelly", with the percent disease indexes of $36.26,43.66$ and $48.59 \%$ at 45,60 and 75 DAS, respectively, which was found yo be significantly superior to direct seed treatment with $P$. fluorescens.

\section{Effect of integrated seed treatments on yield parameters of sunflower}

Seeds treated with carbendazim +iprodione in PEG recorded the highest yield of $17.12 \mathrm{q} /$ ha (Table 1 and Figure 1), with test weight and head diameter of $5.51 \mathrm{~g}$ and $25 \mathrm{~cm}$, respectively, which differed significantly over the seed treatment with carbendazim+iprodione in water which showed an average yield, head diameter and test weight of $16.1 \mathrm{q} / \mathrm{ha}, 23 \mathrm{~cm}$ and $4.30 \mathrm{~g}$, respectively. Still, the highest benefit was obtained with seed treatment with carbendazim+iprodione in water with maximum benefit-cost ratio of 11.66 followed by $\mathrm{PF}$ Jelly $\mathrm{H}$ (i.e., seed treatment with $P$. fluorescens in jelly +hexaconazole foliar spray), with a benefit-cost ratio of 10.53. The direct seed treatment with carbendazim+iprodione recorded an average yield of $15.08 \mathrm{q} / \mathrm{ha}$, which differed significantly with carbendazim+iprodione in water ( $16.10 \mathrm{q} / \mathrm{ha})$ but was found to be on par with respect to test weight (4.03 g) and head diameter $(23.00 \mathrm{~cm})$. Ther seed treatment with $P$. fluorescens in "jelly" as priming agent along with foliar spray with hexaconazole recorded an average yield of $15.92 \mathrm{q} / \mathrm{ha}$ and head diameter of $23.50 \mathrm{~cm}$, which was found on par with the seed treatment with carbendazim + iprodione in water with an average yield and head diameter of $16.10 \mathrm{q} / \mathrm{ha}$ and $23 \mathrm{~cm}$, respectively. which clearly indicated that bio-priming of sunflower seeds with $P$. fluorescens in the form of jelly can be used as an alternative method to seed treatment with chemicals which is ecofriendly and which avoids possible residue problems. The observed improvements due to biopriming of sunflower seeds may be due to priming-induced quantitative changes in 
biochemical content of the seeds and improved membrane integrity (Sung and Chang, 1993). This may be also due to the proliferation of the bioagent P.fluorescens in the priming medium, i.e., jelly. Callan et al. (1990) also stated that the bacterial biocontrol agent may multiply substantially on seed during bio-priming.

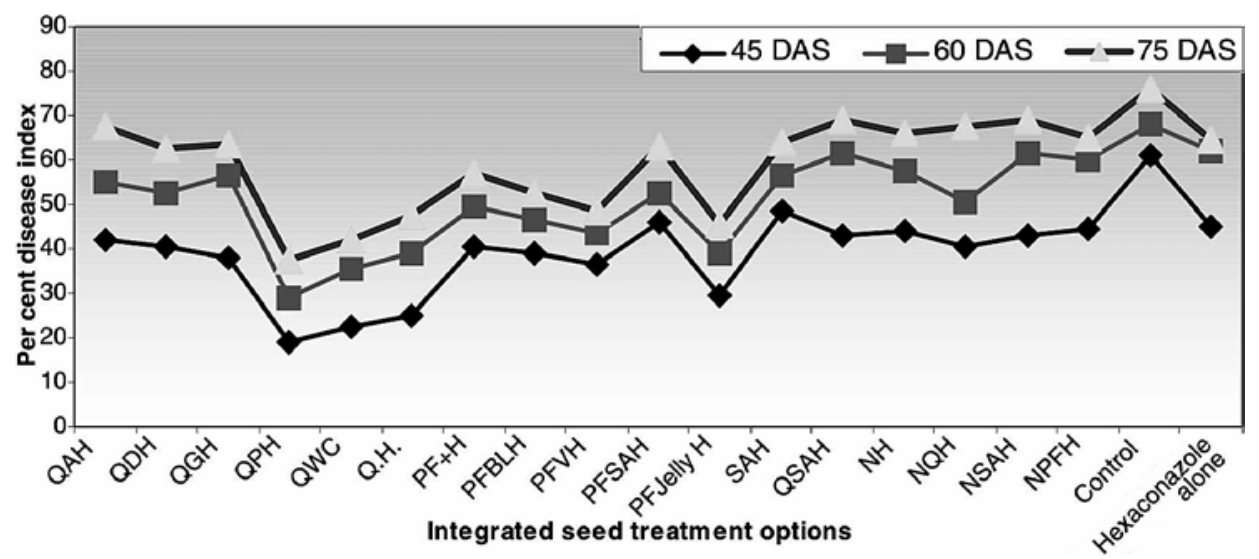

Figure 1: Effect of integrated seed treatment options with priming agents on the percent disease index (PDI) of Alternaria leaf blight of sunflower

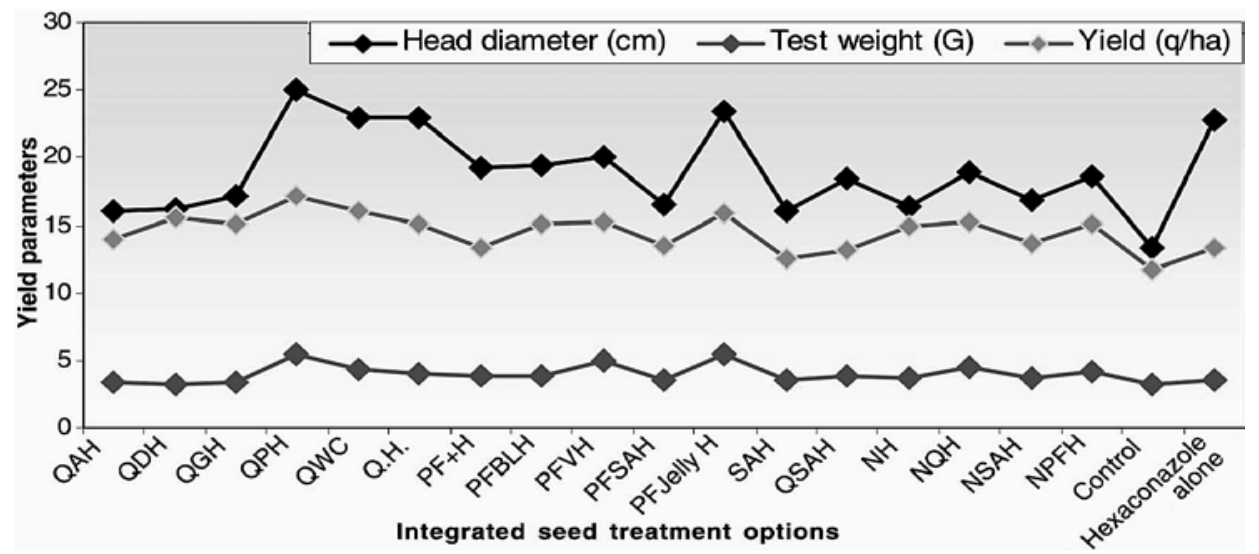

Figure 2: Effect of integrated seed treatment options with priming agents on the management of Alternaria leaf blight in sunflower

\section{CONCLUSIONS}

Results of the present study indicated that bio-priming of sunflower seeds with $P$. fluorescens in "jelly" can be used as an alternative method to seed treatment with chemicals which is economical, ecofriendly and which provides protection to seedlings against seed-borne infections such as Alternaria helianthi causing Alternaria leaf blight. 


\title{
REFERENCES
}

Balasubrahmanyam, N. and Kolte, S.J., 1980. Effect of Alternaria blight on yield components, oil content and seed quality of sunflower. Indian J. Agric. Sci. 50(9): 701-706.

Callan, N.W., Mathre, D.E. and Miller, J.B., 1990. Bio-priming seed treatment for biological control of Pythium ultimum pre emergence damping off in sh2 sweet corn. Plant Disease 74: 368-372.

Hiremath, P.C., Lokesh, M.S. and Kulkarni, M.S., 1993. Seed borne nature of Alternaria helianthi and its effect on seed germination of sunflower. Karnataka J. Agric. Sci. 6: 6869.

Mayee, C.D. and Datar, V.V., 1986. Phytopathometry, Technical Bulletin-I. Marathwada Agricultural University, Parbhani, pp. 46.

Mathre, D.E., Callan, N.W. and Schwend, A., 1994. Factors influencing the control of Pythium ultimum-induced seed decay by seed treatment with Pseudomonas aureofaciens AB254. Crop Protection 13: 301-307.

Papavizas, G.C., 1973. Status of biological control of soil borne plant pathogens. Soil Biology and Biochemistry 5: 709.

Papavizas, G.C. and Lewis, J.A., 1976. Acetone infusion of pyroxychlor into soybean seeds for the control of Phytophthora megasperma var sojae. Plant Disease Reporter. 60: 484488.

Sung, F.J. and Chang, Y.H., 1993. Biochemical activities associated with priming of sweet corn seeds to improve vigour. Seed Sci. and Technology 21: 97-105.

Wheeler, B.E.J., 1969. An Introduction to Plant Diseases, John Wiley and Sons Ltd., London, pp. 1-301.

\section{BIO PELETEADO DE SEMILLAS: UNA HERRAMIENTA POTENCIAL EN EL MANEJO INTEGRADO DE LA ALTERNARIA EN GIRASOL}

\author{
RESUMEN
}

Entre las diferentes opciones para el tratamiento integrado de semilla que se evaluaron para el manejo de la Alternaria del girasol, los mayores beneficios se obtuvieron con el tratamiento de Carbendazim+Iprodione (Quintal) al $0,3 \%$ en agua junto con aplicación foliar de Hexaconazole al $0,1 \%$ seguido por el tratamiento de semillas con Pseudomonas fluorescens $(0,8 \%)$ en gel+aplicación foliar de Hexaconazole. Se puede mejorar la eficacia de Pseudomonas fluorescens como tratamiento de semillas a través del biopeleteado para el tratamiento efectivo y ecológico de la Alternaria del girasol.

\section{BIO-PRÉPARATION DE LA GRAINE: POTENTIALITÉ D'UNE PROTECTION INTÉGRALE DU TOURNESOL CONTRE LA FANURE PROVOQUÉE PAR LE CHAMPIGNON ALTERNARIA}

\author{
RÉSUMÉ
}

Parmi les différents systèmes integrés de traitement de semences testés pour le management de la maladie cause par Alternaria chez le tournesol, le bénéfice le plus important a été obtenu avec un traitement avec le mélange Carbendazim + Iprodione (Quintal) à 0.3 pour cent dans de l'eau accompagné par un spray foliaire de hexaconazole $(0.1 \%)$, suivi par un traitement de semences avec Pseudomonas fluorescens (0.8\%) dans un gel également 
accompagné par le spray foliaire de hexaconazole. L'efficacité de Pseudomonas fluorescens pour l'enrobage des semences peut être augmentée par le bio priming des semences de tournesol pour un management efficace et respectueux de l'environnement de la maladie causée par Alternaria chez le tournesol. 